\title{
Floristic composition of Palpa district, west Nepal
}

\author{
Ras Bihari Mahato \\ Department of Botany, R.R. Multiple Campus \\ Tribhuvan University, Janakpur, Nepal
}

\begin{abstract}
The present study documents the floristic composition of the vascular plants (Pteridophytes, Gymnosperms, and Angiosperms) of Palpa district, West Nepal. A total of 467 species plants belonging to 163 families, 357 genera were recorded from the study area. Among them Pteridophytes are comprised of 37 species, Gymnosperms 2 species and Angiosperms 428 species (Dicotyledones 336 and Monocotyledones 92 species). Floristic analysis showed that Dicotyledones comprise (71.9\%), Monocotyledones (19.7\%), Gymnosperms (0.4\%) and Pteridophytes (8.00\%). Although total plant species were distributed among 163 families and 357 genera, $52.25 \%$ of the species belonged to only ten families. Out of 467 species Hardwickia binata Roxb. is reported as new addition to the flora of Nepal. Five species of threatened plants were recorded from the study area. These are Acacia catechu-threatened (T), Aegle marmelos-(T), Dioscorea deltoidea-(T), Elaeocarpus sphaericus-vulnerable (V) and Rauvolfia serpentinaendangered (E).
\end{abstract}

Key words: Rauvolfia serpentina, pteridophytes, threatened species.

\section{Introduction}

Nepal comprises only $0.1 \%$ of land area on a global scale, but it has a share of $2.04 \%$ (about 6,000 species) of flowering plants. (Shrestha \& Shrestha, 1995). These species are found in the dense tropical monsoon forests of the Terai, in the deciduous and coniferous forests of the subtropical and temperate regions, and in the subalpine and alpine pastures and snow-covered Himalayan peaks (NBS, 2002). It is noteworthy to mention that out of about 410 angiosperms families in the world, 229 (more than 50\%) are represented in Nepal. The estimated number of flowering plants in Nepal is 6,500 species, of which about $4 \%$ species are endemic to the country, and 30\% species are endemic to the Himalayas (WCMC, 1994; Shrestha, 2001). Thus, Nepal has been ranked on 10th highest flowering plant diversity in Asia, and 27th in the world in biodiversity richness (Shrestha, 2001). In the present investigation floristic composition of plants has been conducted in Palpa district West Nepal.

\section{Materials and Methods}

Study area

Palpa district is located in Lumbini zone in the Western Development Region of Nepal. It is situated between $27^{0} 34^{\prime}$ to $27^{\circ} 57^{\prime} \mathrm{N}$ latitudes and $83^{\circ} 15^{\prime}$ to $84^{\circ} 22^{\prime} \mathrm{E}$ longitudes. The total land area of this district is about $1366 \mathrm{sq}$. km. The forest area is about $711 \mathrm{sq} . \mathrm{km}$., which constitutes about $52.11 \%$ of the total land area. In this district, altitude varies from tropical (about $300 \mathrm{~m}$ ) to upper subtropical region $(1900 \mathrm{~m})$. It is bounded by Nawalparasi from east, Arghakhanchi and Gulmi from west, Syangaja, Gulmi and Tanahu from north and Rupandehi and Nawalparasi from south.

The topographical features of Palpa district vary greatly from lowland of north foot of Churiya hill, inner mid-hills with terraces, and lowlands to high Mahabhaat range. Palpa enjoys a 
monsoon type of climate with wet summer and dry winter. During May and June the maximum temperature is recorded in between $28^{\circ}$ and $32^{\circ} \mathrm{C}$. December and January are the coldest months, the minimum temperature reaches to $4^{\circ}-9^{\circ} \mathrm{C}$.

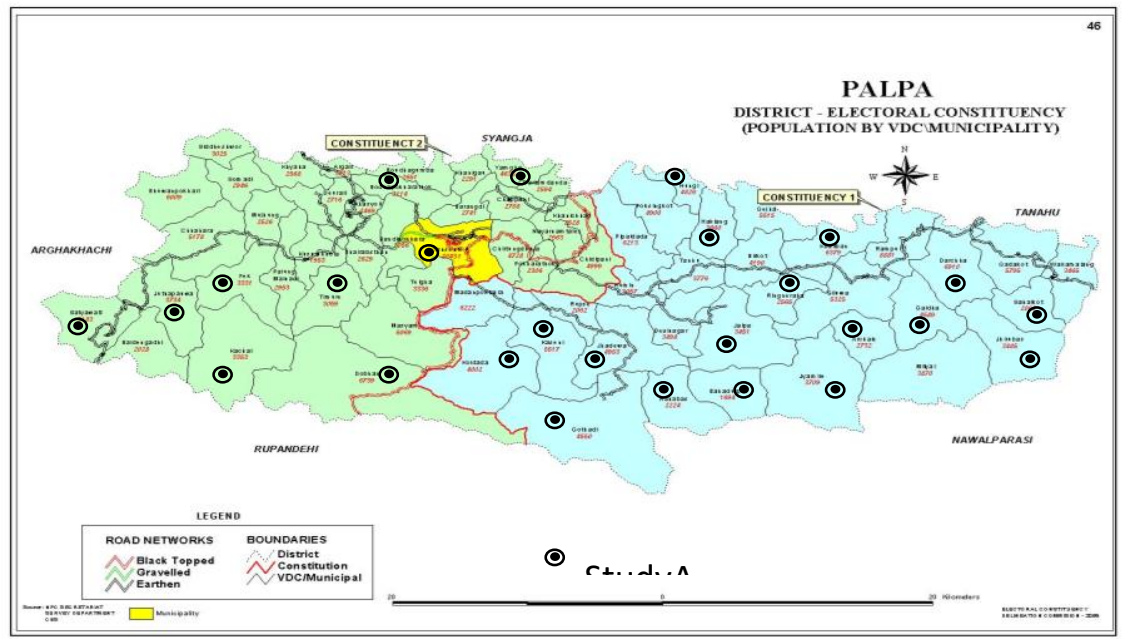

Figure 1. Map of Palpa district, Nepal

Thirty four study areas were selected from different parts of Palpa district for the collection of plant specimens and their identification. These study areas are: 1. Jhumsa (300-400 m) 2. Tiling Danda $(450 \mathrm{~m})$ 3. Hungi $(450 \mathrm{~m})$ 4. Siluwa $(500 \mathrm{~m})$ 5. Khaliban $(500 \mathrm{~m})$ 6.Hattikot Base $(500$ m) 7. Lame Damar $(600 \mathrm{~m})$ 8. Aargali $(650 \mathrm{~m})$ 9. Beruwa $(700 \mathrm{~m}) 10$. Parbas $(900 \mathrm{~m}) 11$. Satyawati tal $(900 \mathrm{~m})$ 12.Huksekot $(900 \mathrm{~m})$ 13. Jyamire $(900 \mathrm{~m}) 14$. Arkhal Danda $(900 \mathrm{~m}) 15$. Bartung $(1000 \mathrm{~m})$ 16. Danam $(1000 \mathrm{~m})$ 17. Jhadewa $(1000-1650 \mathrm{~m}) 18$. Tansen $(1100-1300 \mathrm{~m})$ 19. Khyaha $(1200 \mathrm{~m})$ 20. Phek $(1200 \mathrm{~m})$ 21.Jalpa $(1250-1600 \mathrm{~m}) 22$. Galdha $(1300 \mathrm{~m}) 23$. Humin $(1300 \mathrm{~m})$ 24. Satyawati VDC $(1350 \mathrm{~m}) 25$. Srinagar Danda $(1400 \mathrm{~m}) 26$. Gothadi $(1400$ m) 27. Tanhu $(1400 \mathrm{~m})$ 28. Suke kot $(1500 \mathrm{~m})$ 29. Bhat Gaun $(1500 \mathrm{~m}) 30$. Chahara $(1500-1650$ m) 31. Budichaur $(1600 \mathrm{~m})$ 32. Jherudi (Jhirubas) $(1700 \mathrm{~m})$ 33. Ribdi Kot $(1800 \mathrm{~m}) 34$. Mahabharat Lekh (1900 m).

Plant specimens were collected from their natural habitats in two main seasons, each lasting three to four months at intervals of 15 days. First collection was made after monsoon (August to November) and during monsoon also (June-July). Second collection was made before monsoon (March to May). The places of plant collection are shown in figure 1.

Generally, 3-4 sets of plant specimens for each species were collected from the natural habitats, pressed and dried for voucher specimen. The collected specimens were properly tagged with field numbers. Field study including collection number, local name, uses, locality, altitude, collection date, field notes (habit and habitat) and other relevant information were recorded for each species based on field observation and discussion with local people.

The plants were collected from the natural habitats for herbarium preparation. The plants specimens were pressed, following the standard technique (Alexiades, 1996) for voucher specimen preparation. The plant specimens were identified in field and species that remained unidentified in the field were identified at the National Herbarium and Plant Laboratories, Godavari (KATH) and Central Department of Botany, Tribhuvan University (TUCH), Kirtipur. 
Nomenclature of the plant species follows Hara et al., (1978, 1982), Hara and Williams (1979) and Press et al. (2000). The local name noted in the field and from secondary literature (Shrestha, 1998) was given.

\section{Results}

In the present study 467 species of vascular plants belonging to 163 families, 357 genera were documented from the Palpa district. Among them Pteridophytes are comprised of 37 species, Gymnosperms 2 species and Angiosperms 428 species (Dicotyledones 336 and Monocotyledones 92 species). Specimens of the 412 species were collected, identified and deposited in TUCH. The remaining fifty five species were the representative collection from National Herbarium and Plant Laboratories Godavary, Nepal (KATH). Floristic analysis showed that Dicotyledones comprise (71.9\%), Monocotyledones (19.7\%), Gymnosperms $(0.4 \%)$ and Pteridophytes (8\%). Although total plant species were distributed among 163 families and 357 genera, $52.25 \%$ of the species belonged to only ten families: Gramineae (48 species), Leguminosae (42 species), Compositae (41 species) Labiatae (24 species), Cyperaceae (19 species), Moraceae (14 species), Acanthaceae (13 species), Polygonaceae (12 species), Rubiaceae (11 species) and Rosaceae and Solanaceae (10 species each) (Table 1).

Based on their growth forms, the plant species were classified into trees/ shrubs, undershrubs, climbers, herbs, sedges and grasses. The majority of the species were herbs and undershrubs $(39.2 \%)$, followed by trees and shrubs $(32.3 \%)$, grasses and sedges $(14.3 \%)$, ferns $(8 \%)$ and climbers $(6.2 \%)$ (Table 2).

Table 1. Top ten families of Palpa district.

\begin{tabular}{lcc}
\hline Families & Total species & Percentage \\
\hline Gramineae & 48 & 10.30 \\
Leguminosae & 42 & 8.99 \\
Compositae & 41 & 8.78 \\
Labiatae & 24 & 5.14 \\
Cyperaceae & 19 & 4.06 \\
Moraceae & 14 & 3.00 \\
Acanthaceae & 13 & 2.78 \\
Polygonaceae & 12 & 2.57 \\
Rubiaceae & 11 & 2.35 \\
Rosaceae & 10 & 2.14 \\
Solanaceae & 10 & 2.14 \\
Sub-total & 244 & 52.25 \\
Others & 223 & 47.75 \\
\hline Total & 467 & 100 \\
\hline
\end{tabular}

Table 2. Distribution of species among growth forms in Palpa district.

\begin{tabular}{|c|c|c|c|c|c|c|c|c|c|c|c|c|c|}
\hline 章 & 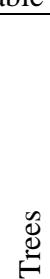 & 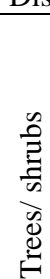 & 蔮 & 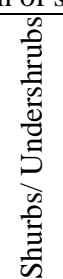 & 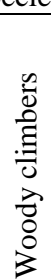 & 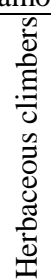 & 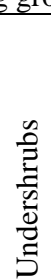 & 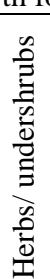 & 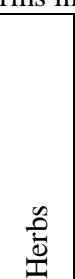 & 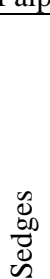 & $\begin{array}{l}0 \\
0 \\
\tilde{0} \\
\tilde{U}\end{array}$ & $\stackrel{0}{0}$ & స్త్ర \\
\hline Families & 34 & 11 & 27 & 2 & 9 & 5 & 11 & 6 & 39 & 1 & 1 & 16 & 163 \\
\hline Genera & 54 & 11 & 59 & 2 & 14 & 7 & 17 & 7 & 122 & 8 & 37 & 19 & 357 \\
\hline Species & 71 & 11 & 67 & 2 & 17 & 12 & 20 & 8 & 155 & 19 & 48 & 37 & 467 \\
\hline
\end{tabular}


Table 3. Threatened plants with cause to threat and IUCN category (1995).

\begin{tabular}{lllc}
\hline Botanical name & Habit \& use & Causes of threat & IUCN category \\
\hline Acacia catechu & Timber tree & Over looping \& wood collection & T \\
Aegle marmelos & Holy tree & Over collection of leaves & $\mathrm{T}$ \\
Dioscorea deltoidea & Climber, edible root Over collection of root & $\mathrm{T}$ \\
Elaeocarpus sphaericus & Holy tree & Over collection of fruit & $\mathrm{V}$ \\
Rauvolfia serpentina & Medicinal shrub & Over collection of plant & E \\
\hline
\end{tabular}

( $\mathrm{T}=$ Threatened, V=Vulnerable,E= Endangered) Shrestha and Joshi (1996)

Out of 467 species 1 species is not reported from Nepal by Hara et al., 1978, 1982 Hara and Williams 1979 and Press et al. (2000). This species include Hardwickia binata Roxb.

Five species of threatened plants were reported from the study area. These are Acacia catechuthreatened (T), Aegle marmelos-(T), Dioscorea deltoidea-(T), Elaeocarpus sphaericusvulnerable (V) and Rauvolfia serpentina-endangered (E) (Table 3). Dioscorea deltoidea and Rauvolfia serpentine are included in the CITES-II.

\section{Discussion}

According to IUCN threat categories (1995) 5 species of threatened plants were reported from the study area. These are Acacia catechu-threatened (T), Aegle marmelos (T), Dioscorea deltoidea (T), Elaeocarpus sphaericus-vulnerable (V) and Rauvolfia serpentina-endangered (E).

Based on plant species reported by Stainton (1972) floristic analysis showed that the flora of Palpa district possesses some eastern and western elements of tropical and subtropical flora. The eastern elements include Castanopsis indica, Maesa chisia, Luculia gratissima, Randia fasciculata, Schima wallichii and Zizyphus incurva. Of these Schima wallichii and Castanopsis indica were the dominant tree species in subtropical zone $(900-1900 \mathrm{~m})$. Similarly the western elements were Dalbergia sissoo and Pinus roxburghii. Of these Dalbergia sissoo was found as dominant species in riverine forest and Pinus roxburghii in subtropical forest (1000-1900m). East Himalayan elements of temperate and alpine flora were Cinnamomum tamala, Colquhounia coccinea, Eurya acuminata, Quercus lanata, Alnus nepalensis, Elsholtzia fruticosa, Lyonia ovalifolia, Mahonia napaulensis, Pyracantha crenulata, Pyrus pashia, and Rhododendron arboreum. The Tibetan elements include Eurya acuminata, Jasminum officinale and Rhododendron arboreum. Jasminum officinale was found as dominant shrub from tropical to upper subtropical zone, whereas Rhododendron arboreum was found as dominant species in upper subtropical forest.

Out of 467 species 1 species is not reported from Nepal by Hara et al., 1978, 1982 Hara and Williams 1979 and Press et al. (2000). This species include Hardwickia binata Roxb.

Present investigation showed that out of 163 families 36 were represented by a single genus and single species and 16 by a single genus and more than one species. Family represented by single genus and single species were Lycopodiaceae, Selaginellaceae, Gleicheniaceae, Hemionitidaceae, Dennsteadtiaceae, Lindsaeaceae, Blechnaceae, Pinaceae, Cupressaceae, Annonaceae, Menispermaceae, Dipterocarpaceae, Bombacaceae, Elaeocarpaceae, Balsaminaceae, Burseraceae, Celastraceae, Rhamnaceae, Anacardiaceae, Crassulaceae, Myrtaceae, Begoniaceae, Sambucaceae, Plumbaginaceae, Sapotaceae, Ebenaceae, Boraginaceae, Nyctaginaceae, Elaeagnaceae, Santalaceae, Piperaceae, Cannabaceae, Juglandaceae, Myricaceae, Betulaceae and Pandanaceae. 
The largest family Gramineae was represented by 37 genera and 48 species. Of these Setaria is comprised of 4 species, Eragrostis 3 species, Chrysopogon, Cymbopogon, Oplismenus, Pennisetum, Pogonatherum and Sporobolus 2 species each. The remaining 23 genera were represented by a single species each. Leguminosae was represented by 23 genera and 42 species. Of these Desmodium was represented by 6 species, Cassia 5 species, Crotalaria 5 species and Acacia 3 species, Aeschynomene, Bauhinia, Millettia and Mimosa 2 species each. The remaining 15 genera were represented by a single species each. Compositae was represented by 30 genera and 41 species. Of these Anaphalis, Blumea and Gnaphalium were represented by 3 species each, Ageratum, Bidens, Inula, Sonchus, Tagetes by 2 species each. The remaining 22 genera were represented by a single species each. Labiatae was represented by 18 genera and 24 species. Of these Rabdosia was represented by 3 species, Elsholtzia, Leucas, Mentha, and Pogostemon by 2 species each. The remaining 13 genera were represented by a single species each. Cyperaceae was represented by 8 genera and 19 species. Of these Cyperus alone had 7 species and Fimbristylis 3 species, Carex, Mariscus and Pycreus 2 species each. The remaining 3 genera had only one species each.

Similarly Moraceae was represented by 3 genera and 14 species. Of these Ficus alone had 11 species Artocarpus 2 species and Morus one species. Acanthaceae was represented by 11 genera and 13 species. Of these Barleria and Justicia had 2 species each. The remaining 9 genera had a single species each. Polygonaceae was represented by 5 genera and 12 species. Of these Persicaria had 4 species, Fagopyrum 3 species, Polygonum and Rumex 2 species each and Aconogonum one species. Rubiaceae was represented by 9 genera and 11 species. Of these, Hedyotis and Wendlandia had 2 species each. The remaining 7 genera were represented by a single species each. Rosaceae was represented by 8 genera and 10 species. Of these Rubus had 3 species and the remaining 7 genera were represented by a single species each. Similarly Solanaceae was represented by 4 genera and 10 species. Of these Solanum was represented by 5 species and Datura by 3 species. The remaining two genera were represented by a single species each.

Genera with largest number of species were Ficus (11 species), Cyperus (7 species), Desmodium (6 species), Crotalaria (5 species), Cassia (5 species), Gentiana (5 species), SolaInum (5 species), Thelypteris (4 species), Ipomoea (4 species), Persicaria (4 species) and Setaria (4 species).

The findings of the present investigation showed many similarities with the tropical and subtropical flora of Nepal reported by Stainton (1972). The tropical and subtropical flora of Palpa district showed dominance of North Indian element. These are composed of deciduous trees well adapted to a climate with a markedly seasonal rainfall. Terminalia alata forest of tropical region is comparable to that of the North Indian moist Terminalia forest. T. alata is also found as main component of tropical forest. Tropical forest upto $700 \mathrm{~m}$ is dominated by sal forest, Shorea robusta-Terminalia alata and Terminalia alata forest. The eastern elements, east Himalayan elements and Tibetan elements are widespread in tropical and subtropical forest. Dalbergia sissoo and Acacia catechu are found as component both of deciduous riverine forest and of subtropical hill forest on hot dry hillsides far from any water. Castanopsis indica and Schima wallichii, east Himalayan species appear as dominant elements of subtropical forest. Similarly Pinus roxburghii reasonably regarded as a west Himalayan species is largely confined to drier region and appeared as most dominant species of subtropical zone. Thus, Palpa district 
showed meeting point of east Himalayan elements and west Himalayan elements. However, oak is less common and is confined to drier region only.

\section{Acknowledgements}

The author is grateful to National Herbarium and Plant Laboratories, Godawari (KATH), Nepal and Central Department of Botany, Tribhuvan University (TUCH), Nepal for their cooperation in identification and providing other facilities. The author is thankful to the local people of Palpa district, who kindly helped during the field trips.

\section{References}

Alexiades, M.N. 1996. Selected Guidelines for Ethnobotanical Research: A Field Manual. The New York Botanical Garden, NY, USA.

Hara, H. \& L.H.J.Williams. 1979. An Enumeration of the flowering plants of Nepal. Vol II. British Museum (Natural History) London, UK.

Hara, H., A.O. Chater \& L.H.J. Williams. 1982. An Enumeration of the flowering Plants of Nepal. Vol. III. British Museum (Natural History) London, UK.

Hara, H., W.T. Stearn \& L.H.J. Williams. 1978. An Enumeration of the Flowering Plants of Nepal, Vol. 1. British Museum (Natural Hostory) London, UK.

NBS. 2002. Nepal Biodiversity Strategy. HMG/Ministry of Forest and Soil Conservation, Kathmandu.

Press, J.K., K.K. Shrestha \& D.A. Sutton. 2005. Webversion of the Annonated Checklist of the Flowering Plants of Nepal (revised and updated) [www.Efloras.Org;www.floraofnepal.org].

Press, J.R., K.K. Shrestha \& D.A. Sutton. 2000. Annotated Checklist of the Flowering Plants of Nepal. The Natural History Museum, London.

Shrestha, K. 1998. Dictionary of Nepalese Plant Names. Mandala Book Point, Kathmandu, Nepal.

Shrestha, K.K. 2001. Flora of Nepal: Characteristics and Taxonomic Treatmrnts. Botanica Orientalis, Central Department of Botany (TU), Kathmandu, pp. 52-60.

Shrestha, T.B. \& K.K. Shrestha. 1995. Flora of Nepal: National Work Plan. Proposal submitted to HMG Department of Plant Resources, Kathmandu, Nepal.

Shrestha, T.B. \& R.M. Joshi. 1996. Rare, endemic and endangered plants of Nepal. WWF Nepal Program, Kathmandu, Nepal.

Stainton, J.D.A. 1972. Forests of Nepal. John Murray Ltd., London

WCMC. 1994. World Conservation Monitoring Centre: Priorities for Conserving Global Species Richness and Endemism (Caldecott, J.O., M.D. Jenkins, T. Johnson \& B. Groombridge Eds.). World Conservation Press, Cambridge. 